\title{
Relationships between vegetation and stomata, and between vegetation and pollen surface soil in Yunnan, Southwest China
}

\author{
SHEN HuaDong ${ }^{1,2}$, LI ChunHai $^{1 *}$, WAN HeWen ${ }^{3}$, TONG GuoBang ${ }^{4}$, \\ LIU JinSong ${ }^{5,6} \&$ DAN Johnson ${ }^{7}$ \\ ${ }^{1}$ State Key Laboratory of Lake Science and Environment, Nanjng Institute of Geography and Limnology, Chinese Academy of Sciences, \\ Nanjing 210008, China; \\ ${ }^{2}$ University of Chinese Academy of Sciences, Beijing 100049, China; \\ ${ }^{3}$ College of Life Sciences, Anhui University, Hefei 230039, China; \\ ${ }^{4}$ Institute of Hydrogeology and Environmental Geology, Chinese Academy of Geological Sciences, Zhengding 050803, China; \\ ${ }^{5}$ Mathematics and Information Science College, Hebei Normal University, Shijiazhuang 050024, China; \\ ${ }^{6}$ The Key Laboratory of Calculation and Application of Hebei Province, Shijiazhuang 050024, China; \\ ${ }^{7}$ Environmental Science, Department of Geography, University of Lethbridge, Alberta T1K 3M4, Canada
}

Received August 26, 2012; accepted November 30, 2012; published online February 21, 2013

\begin{abstract}
Surface pollen and stomata of 61 samples collected in a study area ranging from tropical seasonal rainforest to oak forest (Quercus spinosa) in the Yulong Snow Mountain region in Yunnan, China, are used to distinguish vegetation communities. The results show that tropical seasonal rainforest (and mountain rainforest), south subtropical evergreen broad-leaved forest, and Quercus shrub are distinguished effectively from other vegetation types by analysis of surface pollen. The south subtropical evergreen broad-leaved forest, Pinus kesiya forest and evergreen broadleaf forest are distinguished effectively from other types of vegetation by pollen analysis. However, $P$. yunnanensis forest is not distinguished from other vegetation types, and $P$. armandii, $P$. densata forest and temperate deciduous conifer mixed forest are not distinguished. The over-representation of Pinus pollen is the main reason that these vegetation communities are not distinguished from each other. Conifer stomata analysis is an effective tool for identifying and distinguishing different types of coniferous forest, and this method performs well even with a small number of sampling points.
\end{abstract}

Yunnan, pollen, stomata, topsoil, vegetation, palynology

Citation: Shen H D, Li C H, Wan H W, et al. Relationships between vegetation and stomata, and between vegetation and pollen surface soil in Yunnan, Southwest China. Chin Sci Bull, 2013, 58: 1775-1786, doi: 10.1007/s11434-012-5657-2

Pollen analysis provides important indicators which reconstruct palaeovegetation [1,2]. However, such results are often inaccurate because of uncertainty related to factors affecting pollen production, dissemination, deposition, and identification. Therefore, other assisting means of palaeovegetation reconstruction are needed. At present, there are two main auxiliary methods of reconstructing palaeovegetation. One method is based on examination of plant fossils, which identify species, and provides important information

*Corresponding author (email: chhli@niglas.ac.cn) for accurate reconstruction of palaeovegetation [3]. However, adequate and reliable fossils are often unavailable. The other method relies on identification and quantification of stomata, and provides an accurate means of reconstructing palaeovegetation [4].

In the early 1950's, Trautmann [5] found that observations on conifer stomata served as a potential palaeoenvironmental analysis tool, and that some conifer stomata from vegetation in central Europe are morphologically distinctive. Parshall [6] found that conifer leaves could only transport a very short distance, scattering within approximately $20 \mathrm{~m}$ 
from the origin. The stomata found in closed lake sediments provide information on the plants which grew in the local area, serving as a substitute for observations of plant fossils $[7,8]$. Conifer stomata observations as an important supplement for pollen analysis have received extensive attention and research in Europe, North America, Siberia, and Latin America. In Europe, stomata analyses were applied to study timberline migration [9-13]; in North America, Hansen [14] first used the stomata to study vegetation changes, and further developed the identification standards of the stomata, on the basis of Trautmann's study. However, the scope of applications using stomata methodology has widened. Recently, stomata analysis has been applied to research conducted in alpine and arctic regions and Kennedy evaluated Pinus stomata to distinguish mountain forest from grassland in Dominica [15]. Stomata analysis has also been applied in the Yangtze River Delta and Liupangshan in China $[16,17]$.

The study of vegetation changes in the Yunnan forest area in China, an ecological region strongly influenced by the Asian monsoon, is important for the understanding of monsoons and global climate change. Since the Quaternary, changes in the vertical belt of mountain forest in Northwest Yunnan may due to climate change [18-20]. Determination of the sequence and causes would be supported by accurate methods of reconstruction of the vegetation community. However, studies of surface pollen samples reveal that the accuracy of reconstruction of palaeovegetation by pollen is limited in such areas, because of the over-representation of Pinus pollen [21,22]. In addition, a wide range of gymnosperms are extensively distributed in Yunnan region, varying from cold temperate coniferous forest to subtropical Pinus kesiya forest, in which conifer species are dominant. These conifers have specific significance for ecological and palaeoecological research, if their stomata can be used as an auxiliary method to pollen analysis to reconstruct the ancient vegetation diversity, abundance and distribution. If validated, the method would provide a powerful means of reconstructing paleovegetation and paleoclimate.

The study of the relationship between current pollen observed in standard sampling to corresponding vegetation is a very important step toward the reconstruction of palaeovegetation [23], as a validation and calibration of the methods. Likewise, the study of the relationship of modern pollen stomata to corresponding vegetation can also provide important reference relationships for reconstruction of the ancient vegetation communities. Similar research has been conducted in North America, Central Asia, and South America [5,15,24-28]. This article reports the results of examinations of the relationships among vegetation, pollen and stomata, based on the study of pollen and stomata samples from different types of vegetation in Yunnan. The purpose of the research is to provide evidence and data as a basis for subsequent pollen-vegetation-stomata reconstructions.

\section{Study area}

Yunnan Province lies in the extreme southwest of China $\left(21^{\circ} 9^{\prime}-29^{\circ} 15^{\prime} \mathrm{N}, 97^{\circ} 30^{\prime}-106^{\circ} 12^{\prime} \mathrm{E}\right)$. Complex mountains and valleys were formed during massive uplift and erosion during the end of the Tertiary and Quaternary. Elevation varies considerably, from less than $100 \mathrm{~m}$ on the Red River in southeast Yunnan, to more than $6000 \mathrm{~m}$ in the northwest mountains, within the range of foothills of the Himalayas. In eastern Yunnan, rivers generally flow eastward in relatively shallow valleys, but in the west, the riversf low southward or southeastward, deeply dissecting the plateau landscape by as much as $1000 \mathrm{~m}$. Altitude drops from north to south [29].

The climate of Yunnan is influenced by the interaction of several circulation systems, typically sub-tropical monsoonal, affected by monsoons from the southwest, southeast and northeast, and extra-tropical westerlies. The high altitude strongly influences temperatures within the region. Yunnan has a relatively mild climate, with maximum and minimum annual temperatures of 22.1 and $9.1^{\circ} \mathrm{C}$. Average annual precipitation is distinctly seasonal and varies from $800 \mathrm{~mm}$ in dry valleys to $1700 \mathrm{~mm}$ in the southern and western areas, with $80 \%-90 \%$ during May to October.

The topographical variety within the province has resulted in a rich diversity of vegetation, ranging from tropical rainforest to alpine exposed gravel, and cold desert from Xishuangbanna in southern Yunnan to Yulong Snow Mountain in northwestern Yunnan, within a straight-line distance of more than $600 \mathrm{~km} \mathrm{[29].}$

Within the study area, a total of 61 surface pollen and stomata samples were taken from Xishuangbanna in southern Yunnan to Yulong Snow Mountain region in northwestern Yunnan (Figure 1). The main vegetation types are shown in Figure 1 and Table 1.

\section{Materials and methods}

In 2005 and 2006, samples were collected from the southern tropical rainforest in Xishuangbanna to the northern cold coniferous forest of Yulong Snow Mountain in Yunnan (Figure 1). The main material collected in each sample is topsoil and moss. At each sampling point, 4-5 samples of moss or topsoil were randomly selected and collected within an area of approximately $100 \mathrm{~m}^{2}$, then combined into one bulked sample and tagged with the location and altitude of each sampling point by GPS (Table 1). In order to study whether the stomata can accurately indicate the existence of cold temperate coniferous vegetation communities, samples were also collected in the forest sites where cold temperate tree species are not dominant to test the accuracy of analysis of stomata as indicators.

Standard hydrofluoric (HF) methods are used to prepare the samples treatment [30]. The number of pollen in each sample was counted, usually at least 500 grains. However, 


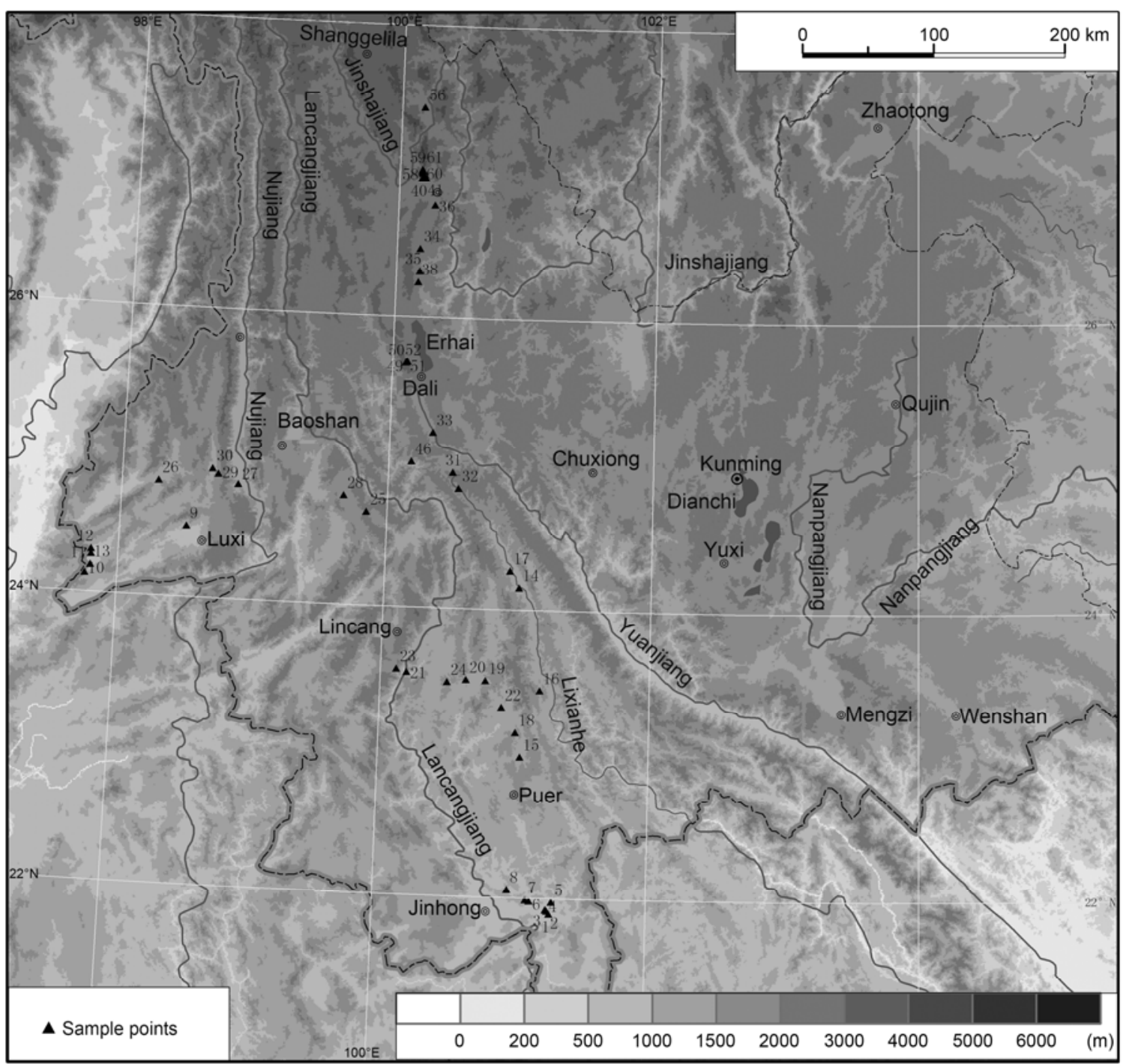

Figure 1 The locations of the sampling points.

samples with less than 500 grains of pollen were counted in a few samples because the content of the pollen is very low in those cases. At the same time, stomata were identified in the samples [24,31,32]. The percentages of pollen and stomata were calculated using the terrestrial plants as the base, and at the same time, the percentages of fern spores found in the samples were calculated using the sum of the total number of terrestrial plants and the total number of fern spores as the base. The calculation and mapping is based on software programs Tilia and TGView [33,34].

To study the relationship between pollen and modern vegetation, the pollen data is subjected to Detrended Correspondence Analysis (DCA) analysis. This method is used for pollen types for which the content of those pollen is more than $2 \%$ and those types appeared in more than 3 samples. CANOCO4.5 software is used to calculate results [35], and the square root transformation is used to convert the percentage data of the pollen counts.

\section{Results}

\subsection{Surface pollen and stomata}

More than 300 genera of pollen were identified in the 61 samples. The percentages of surface pollen and stomata are shown in Figure 2 according to the vegetation types, pollen and stomata (Figures 2 and 3).

(i) Tropical mountain rainforest and seasonal forest. Tropical and subtropical species (except Pinus) are dominant in the main woody pollen, including Lithocarpus/ Castanea, Castanopsis, Quercus evergreen, Mallotus, Macaranga, Moraceae, Eurya genus, Magnolia, Ficus and Theaceae. Herbs are mainly Gramineae, Artemisia and Euphorbiaceae. The content of fern spores is high (25\%-95\%) and with multiple types. Samples 1 and 7 contained some stomata which cannot be identified.

(ii) South subtropical broadleaf forest. The relative amountof Pinus pollen in samples 9, 10 and 14 is dominant 
Table 1 Elevation, latitude, longitude, vegetation types and the main vegetation of the sampling locations

\begin{tabular}{|c|c|c|c|c|c|}
\hline $\begin{array}{l}\text { Sampling } \\
\text { points }\end{array}$ & $\begin{array}{c}\text { Elevation } \\
(\mathrm{m})\end{array}$ & $\begin{array}{c}\text { Latitude } \\
\left({ }^{\circ}\right)\end{array}$ & $\begin{array}{l}\text { Longitude } \\
\left({ }^{\circ}\right)\end{array}$ & Vegetation types & Main vegetation \\
\hline 1 & 557 & 21.891 & 101.296 & seasonal rainforest & $\begin{array}{l}\text { Lagerstroemia, Yushania, Ficus, Ormosia, Duabanga gran- } \\
\text { diflora, Macaranga denticulata, Pinus tabulaeformis, Ster- } \\
\text { culia, Elaeocarpus, Malugay, Homalium cochinchinense, } \\
\text { Lithocarpus, Dendrobenthamia angustata (Chun) Fang }\end{array}$ \\
\hline 2 & 673 & 21.911 & 101.281 & seasonal rainforest & $\begin{array}{l}\text { Caryota ochlandra Hance, Ficus, Lithocarpus, Macaranga } \\
\text { denticulata, Acacia pennata, Phoebe, Ficus }\end{array}$ \\
\hline 3 & 586 & 21.919 & 101.271 & seasonal rainforest & $\begin{array}{l}\text { Tetrameles, Musa paradisiaca, Dimocarpus longgana Lour., } \\
\text { Schefflera octophylla(Lour.)Harms, Erythrina indica Lam, } \\
\text { Combretaceae nom. conserv. }\end{array}$ \\
\hline 4 & 592 & 21.92 & 101.27 & seasonal rainforest & $\begin{array}{l}\text { Carallia brachiata, mangrove, Ficusstricta, Melia azedarach, } \\
\text { Semecarpus anacardius L.f., Macaranga tanarius, Bac- } \\
\text { caurea ramiflora Lour }\end{array}$ \\
\hline 5 & 589 & 21.976 & 101.312 & tropical mountain rainforest & $\begin{array}{l}\text { same as above, Rosa spp., Duabanga grandiflora, Ormosia, } \\
\text { Yushania, Olea, Arecaceae, Magnolia henryi Dunn }\end{array}$ \\
\hline 6 & 781 & 21.979 & 101.148 & tropical mountain rainforest & $\begin{array}{l}\text { Mainly: Ficus, Clerodendrum bungei, Macaranga tanarius, } \\
\text { Meliaceae, Schima superba Gardn et Champ, Few: Betula, } \\
\text { Mussaenda pubescens, Rubia cordifolia, Bischofia poly- } \\
\text { carpa }\end{array}$ \\
\hline 7 & 1074 & 21.986 & 101.12 & tropical mountain rainforest & $\begin{array}{l}\text { Bauhinia purpurea } \mathrm{L} ., \text { Cinnamomum rigidissimum, M. basjoo, } \\
\text { P. australis, Ficus, Duabanga grandiflora, Paramichelia } \\
\text { baillonii (Pierre) } \mathrm{Hu}\end{array}$ \\
\hline 8 & 800 & 22.056 & 100.984 & tropical mountain rainforest & $\begin{array}{l}\text { Schima superba Gardn et Champ, Castanopsis fargesii, } \\
\text { Lauraceae, Duabanga grandiflora, Sapotaceae, Rhodoleia, } \\
\text { Hamamelidaceae, Rhus chinensis, Ficus }\end{array}$ \\
\hline 9 & 1506 & 24.815 & 98.833 & $\begin{array}{l}\text { south subtropical evergreen broad-leaved } \\
\text { forest }\end{array}$ & Castanopsis fargesii, Lauraceae, Theaceae \\
\hline 10 & 1255 & 24.213 & 97.794 & $\begin{array}{l}\text { south subtropical evergreen broad-leaved } \\
\text { forest }\end{array}$ & Castanopsis fargesii, Lauraceae, Theaceae \\
\hline 11 & 1559 & 24.378 & 97.823 & $\begin{array}{l}\text { south subtropical evergreen broad-leaved } \\
\text { forest }\end{array}$ & Castanopsis fargesii, Lauraceae, Theaceae \\
\hline 12 & 1760 & 24.392 & 97.822 & $\begin{array}{l}\text { south subtropical evergreen broad-leaved } \\
\text { forest }\end{array}$ & Castanopsis fargesii, Lauraceae, Theaceae \\
\hline 13 & 1550 & 24.392 & 97.822 & $\begin{array}{l}\text { south subtropical evergreen broad-leaved } \\
\text { forest }\end{array}$ & Castanopsis fargesii, Lauraceae, Theaceae \\
\hline 14 & 1120 & 24.152 & 101.011 & $\begin{array}{l}\text { south subtropical evergreen broad-leaved } \\
\text { forest }\end{array}$ & $\begin{array}{l}\text { B. ceiba, Ficus microcarpa, Aleurites moluccana, Man- } \\
\text { gifera indica Linn, Cyclobalanopsis, Quercus acutissima } \\
\text { Carruth, Syzygium jambos (L.) Alston. }\end{array}$ \\
\hline 15 & 1333 & 22.981 & 101.052 & Pinus kesiya forest & $\begin{array}{l}\text { Phyllanthus emblica Linn., Betula, Pinus kesiya, Toxi- } \\
\text { codenddron sylvestre (Sieb. et Zucc.) O.Kunrze., } \\
\text { Ternstroemia, Schima superba Gardn et Champ, Ficus al- } \\
\text { tissima Bl., Amla }\end{array}$ \\
\hline 16 & 1265 & 23.446 & 101.186 & Pinus kesiya forest & $\begin{array}{l}\text { Pinus kesiya, Castanopsis fargesii, Ailanthus altissima (Mill.) } \\
\text { Swingle, Ficus microcarpa, Schima superba Gardn et } \\
\text { Champ }\end{array}$ \\
\hline 17 & 1204 & 24.266 & 100.941 & Pinus kesiya forest & Pinus kesiya, Ficus \\
\hline 18 & 1207 & 23.15 & 101.012 & Pinus kesiya forest & $\begin{array}{l}\text { Pinus kesiya, Toxicodendron verniciflua(Stokes) F.A.Barkl } \\
\text { Cinnamomum camphora (L.) Presl, Rutaceae }\end{array}$ \\
\hline 19 & 1149 & 23.505 & 100.78 & Pinus kesiya forest & $\begin{array}{l}\text { Pinus kesiya, Toxicodendron verniciflua(Stokes )F.A.Barkl } \\
\text { Cinnamomum camphora }(\text { L.) Presl, Rutaceae }\end{array}$ \\
\hline 20 & 1436 & 23.507 & 100.635 & Pinus kesiya forest & $\begin{array}{l}\text { Pinus kesiya, Fagaceae, Amelanchier, C. bungei, Alsophila } \\
\text { spinulosa (Hook.) Tryon }\end{array}$ \\
\hline 21 & 920 & 23.55 & 100.193 & Pinus kesiya forest & $\begin{array}{l}\text { Fagaceae, Pinus kesiya, Amelanchier, C. bungei, Alsophila } \\
\text { spinulosa (Hook.) Tryon, }\end{array}$ \\
\hline 22 & 932 & 23.324 & 100.905 & Pinus kesiya forest & $\begin{array}{l}\text { Fagaceae, Pinus kesiya, Amelanchier, C. bungei, Alsophila } \\
\text { spinulosa (Hook.) Tryon, }\end{array}$ \\
\hline 23 & 1520 & 23.569 & 100.116 & Pinus kesiya forest & $\begin{array}{l}\text { Fagaceae, Pinus kesiya, Amelanchier, C. bungei, Alsophila } \\
\text { spinulosa (Hook.) Tryon }\end{array}$ \\
\hline 24 & 1723 & 23.489 & 100.495 & Pinus kesiya forest & $\begin{array}{l}\text { Fagaceae, Pinus kesiya, Amelanchier, C. bungei, Alsophila } \\
\text { spinulosa (Hook.) Tryon }\end{array}$ \\
\hline 25 & 2178 & 24.644 & 99.845 & Pinus kesiya forest & $\begin{array}{l}\text { Fagaceae, Pinus kesiya, Amelanchier, C. bungei, Alsophila } \\
\text { spinulosa (Hook.) Tryon, }\end{array}$ \\
\hline 26 & 1159 & 24.793 & 98.273 & evergreen broad-leaved forest & $\begin{array}{l}\text { Lithocarpus echinotholus, Cyclobalanopsis glaucoides } \\
\text { Schottky, C. delavayi Franch., Castanopsis delavayi Franch., } \\
\text { Quercus }\end{array}$ \\
\hline
\end{tabular}


(Continued)

\begin{tabular}{|c|c|c|c|c|c|}
\hline $\begin{array}{l}\text { Sampling } \\
\text { points }\end{array}$ & $\begin{array}{c}\text { Elevation } \\
(\mathrm{m})\end{array}$ & $\begin{array}{l}\text { Latitude } \\
\left({ }^{\circ}\right)\end{array}$ & $\begin{array}{l}\text { Longitude } \\
\left({ }^{\circ}\right)\end{array}$ & Vegetation types & Main vegetation \\
\hline 27 & 1250 & 24.791 & 98.873 & evergreen broad-leaved forest & Lithocarpus echinotholus \\
\hline 28 & 1563 & 24.75 & 99.67 & evergreen broad-leaved forest & Lithocarpus echinotholus \\
\hline 29 & 1606 & 24.857 & 98.721 & evergreen broad-leaved forest & Lithocarpus echinotholus \\
\hline 30 & 1679 & 24.892 & 98.676 & evergreen broad-leaved forest & Lithocarpus echinotholus \\
\hline 31 & 2054 & 24.935 & 100.486 & P. yunnanensis forest & $\begin{array}{l}\text { Eucalyptus, secondary P. yunnanensis Franch., Quercus, } \\
\text { Schima superba Gardn et Champ }\end{array}$ \\
\hline 32 & 1686 & 24.824 & 100.533 & P. yunnanensis forest & secondary $P$. yunnanensis Franch. \\
\hline 33 & 1919 & 25.206 & 100.325 & P. yunnanensis forest & $\begin{array}{l}\text { Rosaceae, P. yunnanensis Franch., Eucalyptus, Cyclob- } \\
\text { alanopsis }\end{array}$ \\
\hline 34 & 2324 & 26.468 & 100.175 & P. yunnanensis forest & Eucalyptus, $P$. yunnanensis Franch. \\
\hline 35 & 2255 & 26.314 & 100.178 & P. yunnanensis forest & $\begin{array}{l}\text { P. yunnanensis Franch., Alnus nepalensis D.Don, Keteleeria } \\
\text { fortunei (Murr) Carr, Quercus, Lithocarpus }\end{array}$ \\
\hline 36 & 2425 & 26.771 & 100.278 & P. yunnanensis forest & $\begin{array}{l}\text { P. yunnanensis Franch., Photinia prionophylla (Franch.) } \\
\text { Schneid., P. armandii Franch. }\end{array}$ \\
\hline 37 & 2700 & 26.955 & 100.202 & $P$. armandii and $P$. densata forest & $\begin{array}{l}\text { P. densata Mast., P. yunnanensis Franch., P. armandii } \\
\text { Franch., Rhododendron }\end{array}$ \\
\hline 38 & 2371 & 26.24 & 100.169 & $P$. armandii and $P$. densata forest & $\begin{array}{l}\text { Duercus spinosa David ex Fr., Rhododendron, Heaceae, } \\
\text { Myrica rubra (Lour.)Zucc., Keteleeria fortunei (Murr) } \\
\text { Carr, Rhododendron delavayi Franch, Caprifoliaceae, P. } \\
\text { armandii Franch. }\end{array}$ \\
\hline 39 & 2838 & 26.954 & 100.192 & $P$. armandii and $P$. densata forest & P. armandii Franch., Populus, Salix \\
\hline 40 & 2948 & 26.952 & 100.17 & $P$. armandii and $P$. densata forest & $\begin{array}{l}\text { Picea, P. armandii Franch., P. densata Mast., Viburnum } \\
\text { dilatatum Thunb, Populus davidiana Dode, Duercus spi- } \\
\text { nosa David ex Fr. }\end{array}$ \\
\hline 41 & 3054 & 26.953 & 100.182 & $P$. armandii and $P$. densata forest & $\begin{array}{l}\text { P. armandii Franch., P. densata Mast., Populus davidiana } \\
\text { Dode, Picea, Abies }\end{array}$ \\
\hline 42 & 3138 & 26.969 & 100.182 & $P$. armandii and $P$. densata forest & $\begin{array}{l}\text { P. armandii Franch., P. densata Mast., Quercus spinosa } \\
\text { David ex Fr., Populus, Rhododendron }\end{array}$ \\
\hline 43 & 3262 & 26.988 & 100.174 & $P$. armandii and $P$. densata forest & $\begin{array}{l}\text { P. densata Mast., Tsuga, P. armandii Franch., Paeonia } \\
\text { delavayi var. lutea (Franch.) Finet. Et Gagnep. }\end{array}$ \\
\hline 44 & 3305 & 26.995 & 100.176 & P. densata forest & $\begin{array}{l}\text { Horse-intoxicated Pieris, P. densata Mast., Q. pannosa } \\
\text { Hand.-Mazz., Rhododendron, Viburnum dilatatum Thunb, } \\
\text { P. armandii Franch. }\end{array}$ \\
\hline 45 & 3321 & 26.998 & 100.17 & P. densata forest & P. densata Mast., Rhododendron \\
\hline 46 & 3369 & 27.002 & 100.17 & P. densata forest & P. densata Mast., Quercus, Rhododendron \\
\hline 47 & 3152 & 25.689 & 100.111 & $\begin{array}{l}\text { secondary shrub after temperate broad- } \\
\text { leaved mixed conifer forest }\end{array}$ & Spiraea, Polygonaceae \\
\hline 48 & 3220 & 25.684 & 100.1 & $\begin{array}{l}\text { secondary shrub after temperate broad- } \\
\text { leaved mixed conifer forest }\end{array}$ & Rubus \\
\hline 49 & 3152 & 25.689 & 100.111 & $\begin{array}{l}\text { temperate broad-leaved mixed conifer } \\
\text { forest }\end{array}$ & $\begin{array}{l}\text { Lithocarpus, Populus, Tsuga, Phyllostachys pubescens } \\
\text { Mazel ex H. de Lehaie }\end{array}$ \\
\hline 50 & 3287 & 25.684 & 100.1 & $\begin{array}{l}\text { temperate broad-leaved mixed conifer } \\
\text { forest }\end{array}$ & Quercus, Abies, Tsuga, Rhododendron, bamboo \\
\hline 51 & 3307 & 25.685 & 100.104 & $\begin{array}{l}\text { temperate broad-leaved mixed conifer } \\
\text { forest }\end{array}$ & Quercus, Abies, Tsuga, Rhododendron, bamboo \\
\hline 52 & 3307 & 25.685 & 100.104 & $\begin{array}{l}\text { temperate broad-leaved mixed conifer } \\
\text { forest }\end{array}$ & Quercus, Abies, Tsuga, Rhododendron, bamboo \\
\hline 53 & 3392 & 27.003 & 100.171 & $\begin{array}{l}\text { temperate broad-leaved mixed conifer } \\
\text { forest }\end{array}$ & Rhododendron, Abies \\
\hline 54 & 3440 & 27.004 & 100.173 & Quercus shrub & Q. spinosa Rhododendron, Abies, Picea \\
\hline 55 & 3472 & 27.007 & 100.174 & Quercus shrub & Q. spinosa Rhododendron, Abies, Picea \\
\hline 56 & 3495 & 27.441 & 100.174 & Quercus shrub & Q. spinosa Rhododendron, Abies, Picea \\
\hline 57 & 3530 & 27.009 & 100.173 & Quercus shrub & Q. spinosa, Rhododendron, Abies \\
\hline 58 & 3571 & 27.01 & 100.172 & Quercus shrub & Q. spinosa, Rhododendron, Abies \\
\hline 59 & 3581 & 27.011 & 100.172 & Quercus shrub & $\begin{array}{l}\text { Q. pannosa Hand.-Mazz., Populus davidiana Dode, } Q \text {. spi- } \\
\text { nosa, Abies }\end{array}$ \\
\hline 60 & 3625 & 27.013 & 100.171 & Quercus shrub & Q. spinosa \\
\hline 61 & 3679 & 27.014 & 100.172 & Quercus shrub & Q. spinosa \\
\hline
\end{tabular}



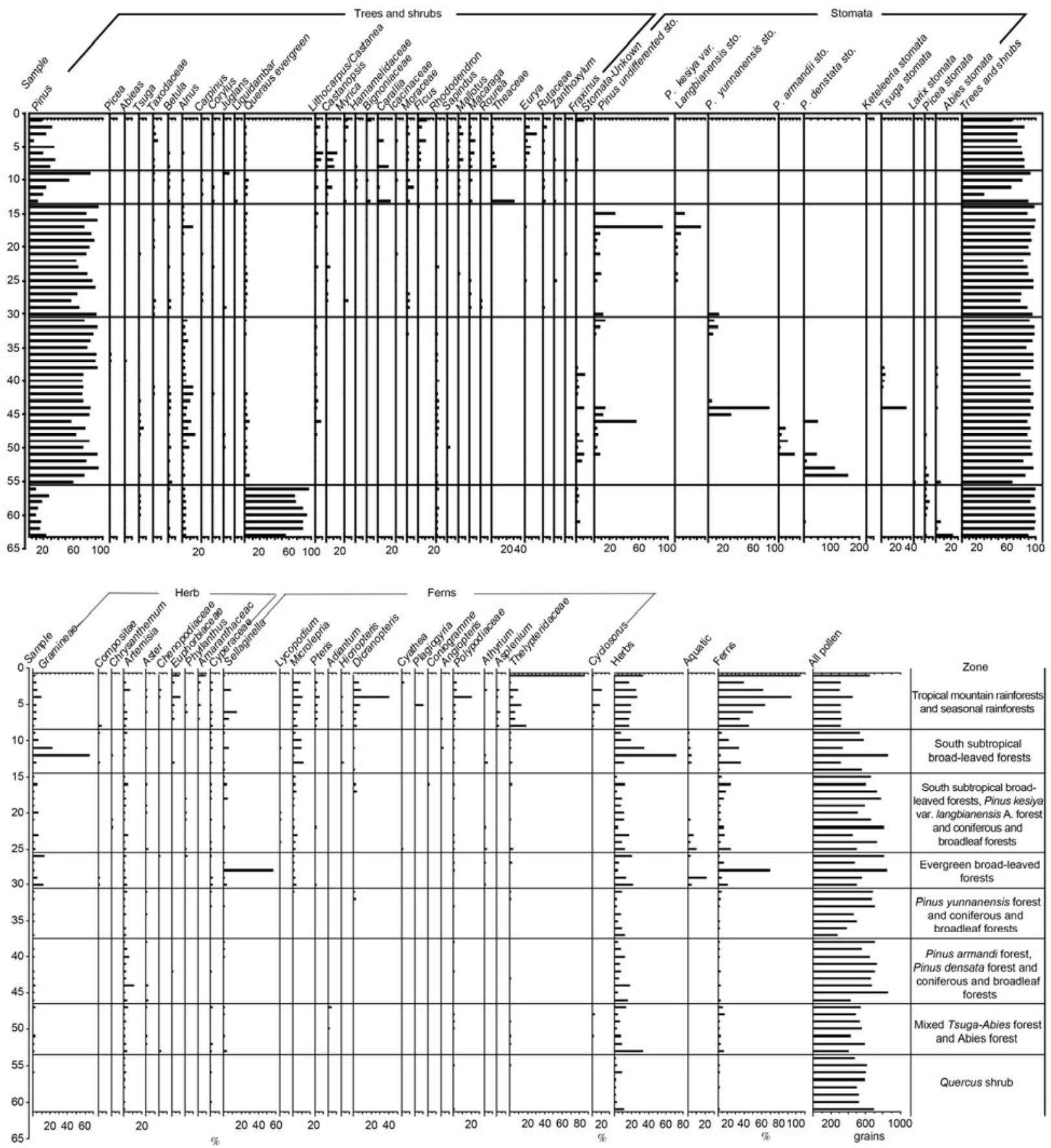

Figure 2 The percentages of surface pollen and stomata.

(maximum of $82.5 \%$ ). The main woody pollen types are Moraceae, Theaceae, Quercus evergreen, Castanopsis and Lithocarpus/Castanea. The highest proportion of Gramineae in herb pollen is $65.5 \%$, most of which is more than $38 \mu \mathrm{m}$ $(64.1 \%)$. Fern spore content is relatively high (5\%-28.5\%).

(iii) South subtropical P. kesiya forest. Pinus pollen accounted for $57.4 \%-93.8 \%$ and the content of broad-leaved tree pollen is relatively low, mainly including Alnus, Lithocarpus/Castanea, Castanopsis and Quercus evergreen; other pollen are mainly mainly Gramineae and Artemisia; ferns accounted for $3.5 \%-59.8 \%$ of the total pollen, which are the highest $(50.5 \%)$. Conifer stomata are dominant, with mainly P. kesiya and Pinus sp. (Pinus which can not be identified, is recorded simply as Pinus).

(iv) Central subtropical evergreen broad-leaved forest. Pinus pollen is dominant $(56.2 \%-90.9 \%)$ here, and other broad-leaved tree pollen types are mainly Quercus evergreen, Lithocarpus/Castanea, Myrica and Moraceae. Herb pollen are Gramineae and Artemisia, as is the case in other vegetation types, and fern spores are mainly Selaginella. 


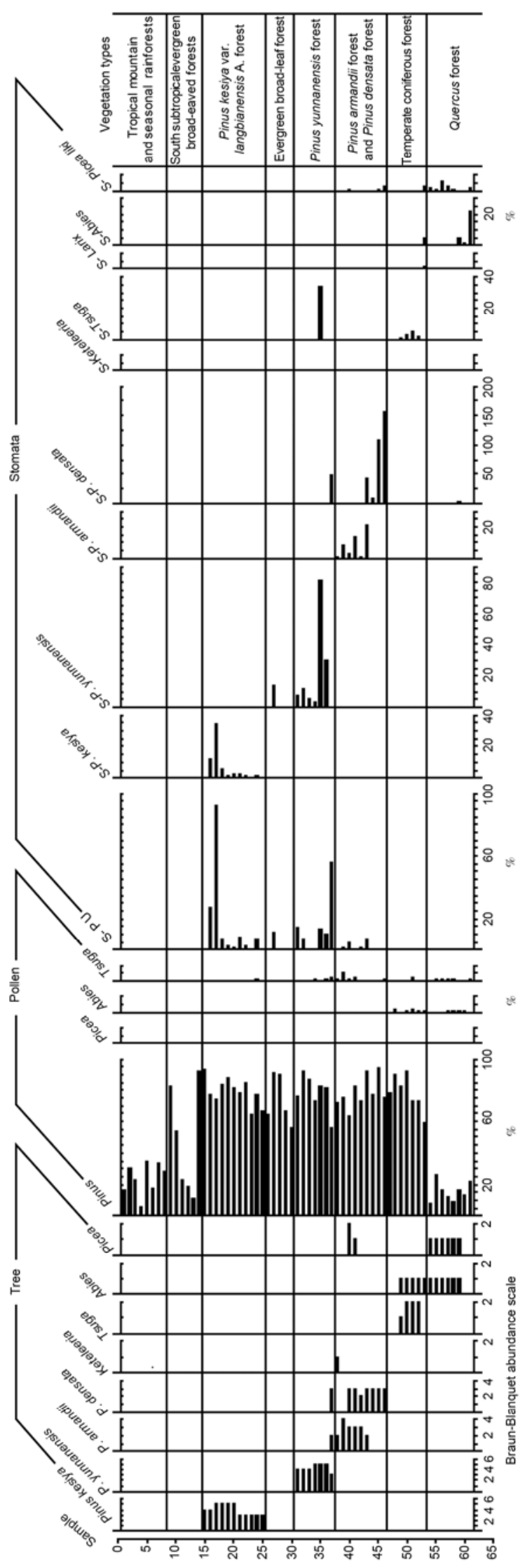

Figure 3 The percentages of surface pollen and stomata according to types of vegetation, pollen and stomata.
Sample 27 contained Pinus and P. yunnanensis stomata.

(v) P. yunnanensis forest. Pinus pollen accounted for $55.7 \% \%-91.7 \%$ of the total. The maximum content of $T s u-$ $g a$ is $1.9 \%$ and broad-leaved tree pollen is mainly from $\mathrm{Al}$ nus (1.7\%-10.4\%), Lithocarpus/Castanea, Quercus evergreen and Betula. Herb pollen is mainly Artemisia. P. yunnanensis Franch. is found in all samples except one (Sample 37). Stomata are found in all samples except Sample 34. The content of Tsuga stomata in Sample 36 is high and $P$. densata stomata is found in Sample 37.

(vi) $P$. armandii and $P$. dansata forest. Pinus pollen content is $63.4 \%-93.7 \%$ and Tsuga appeared in all samples. Broad-leaved tree pollen types are mainly Alnus, Betula, Juglans, Quercus evergreen and Lithocarpus/Castanea. Shrubs are mainly Rhododendron. Herb pollen types are mainly Gramineae, Aster and Artemisia. P. armandii stomata are found in samples 38-43 and Coniferous stomata from higher elevation area are found in samples 43-46.

(vii) Temperate broad-leaved mixed conifer forest. Pinus pollen is dominant here. Tsuga and Abies pollen are rare. Broad-leaved trees are mainly Alnus and Lithocarpus/Castanea. Samples 47 and 48 are the secondary shrub, with no stomata found in them. Tsuga and Abies stomata are found in the samples from sites where Abies and Tsuga appeared. Sample 53 contained larch, Tsuga and Abies stomata.

(viii) Quercus shrub. Pinus pollen content is lower, and samples contained mainly Quercus evergreen pollen, and typically lesser amounts of Alnus. These samples contain Picea and Abies stomatas, with Picea mainly found in low elevation samples and Abies mainly appearing in higher elevation samples.

\subsection{DCA analysis}

The results of the first and second axis coordinate chart of the DCA analysis are shown in Figures 4 and 5. The first Eigenvalue of 0.428 cumulatively explain $21.2 \%$ of the pollen changes. In the sample distribution diagram (Figure 4), tropical vegetation located in the negative terminal of the first axis while cold temperate vegetation distributed in the positive terminal of the first axis. In the species distribution diagram (Figure 5), fern spores and tropical species are distributed in the negative terminal of the first axis, while Picea, Abies and Quercus evergreen are distributed in the positive terminal. The first axis reflect the temperature gradient, and fully distinguish the tropical seasonal forest, montane rain forest and $Q$. spinosa shrubs from other vegetation types, and also distinguish subtropical evergreen broadleaved forest, evergreen broad-leaved forest and P. kesiya forest from other vegetation types. However, it is difficult to draw distinctions among these three classes. $P$. yunnanensis forest are not reliably distinguished from other vegetation types. A portion of these samples overlap with the evergreen broadleaf forest and $P$. kesiya in the lower latitude. A portion of the samples overlap with $P$. armandii forest vegetation 


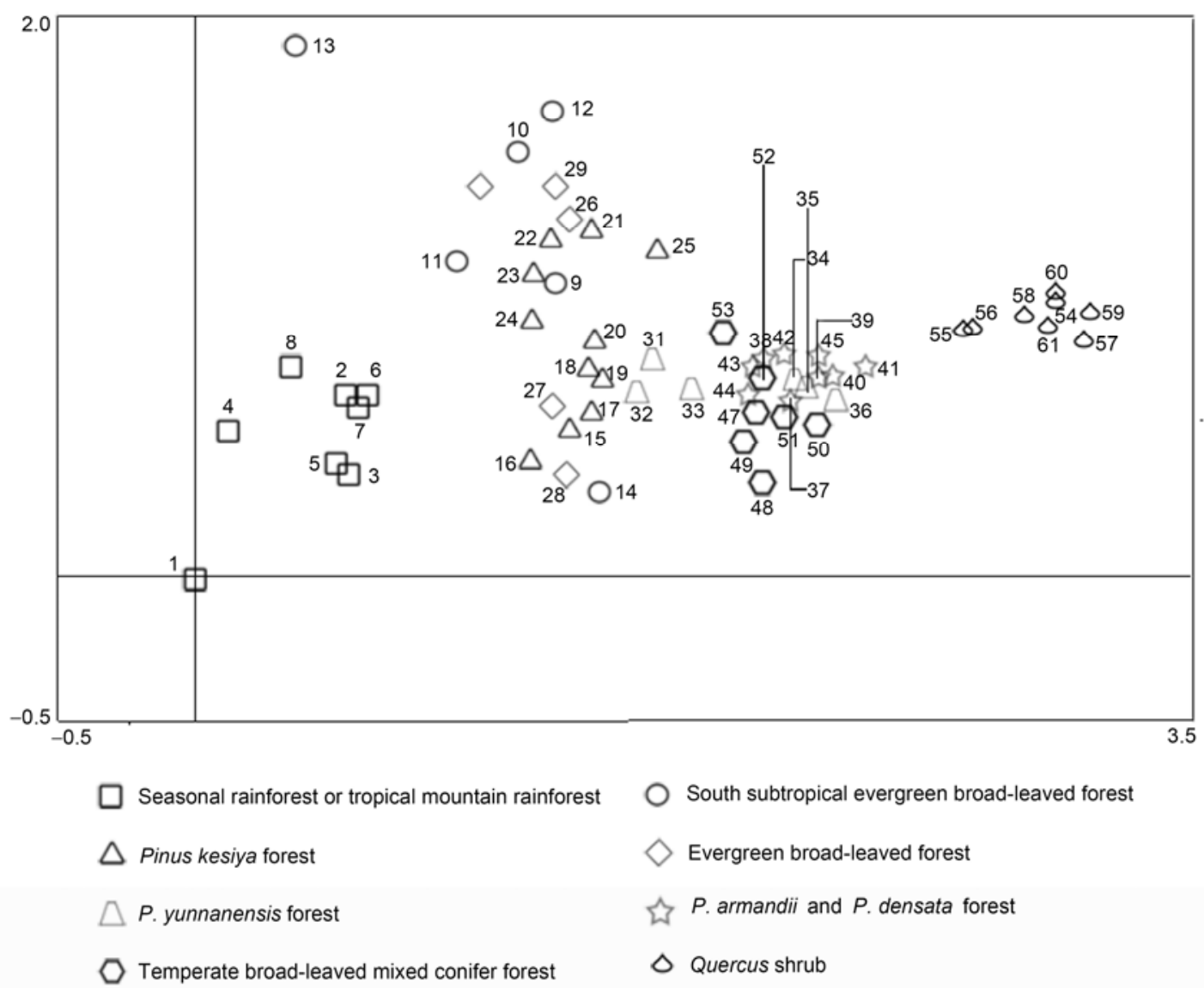

Figure 4 The sample distribution diagram.

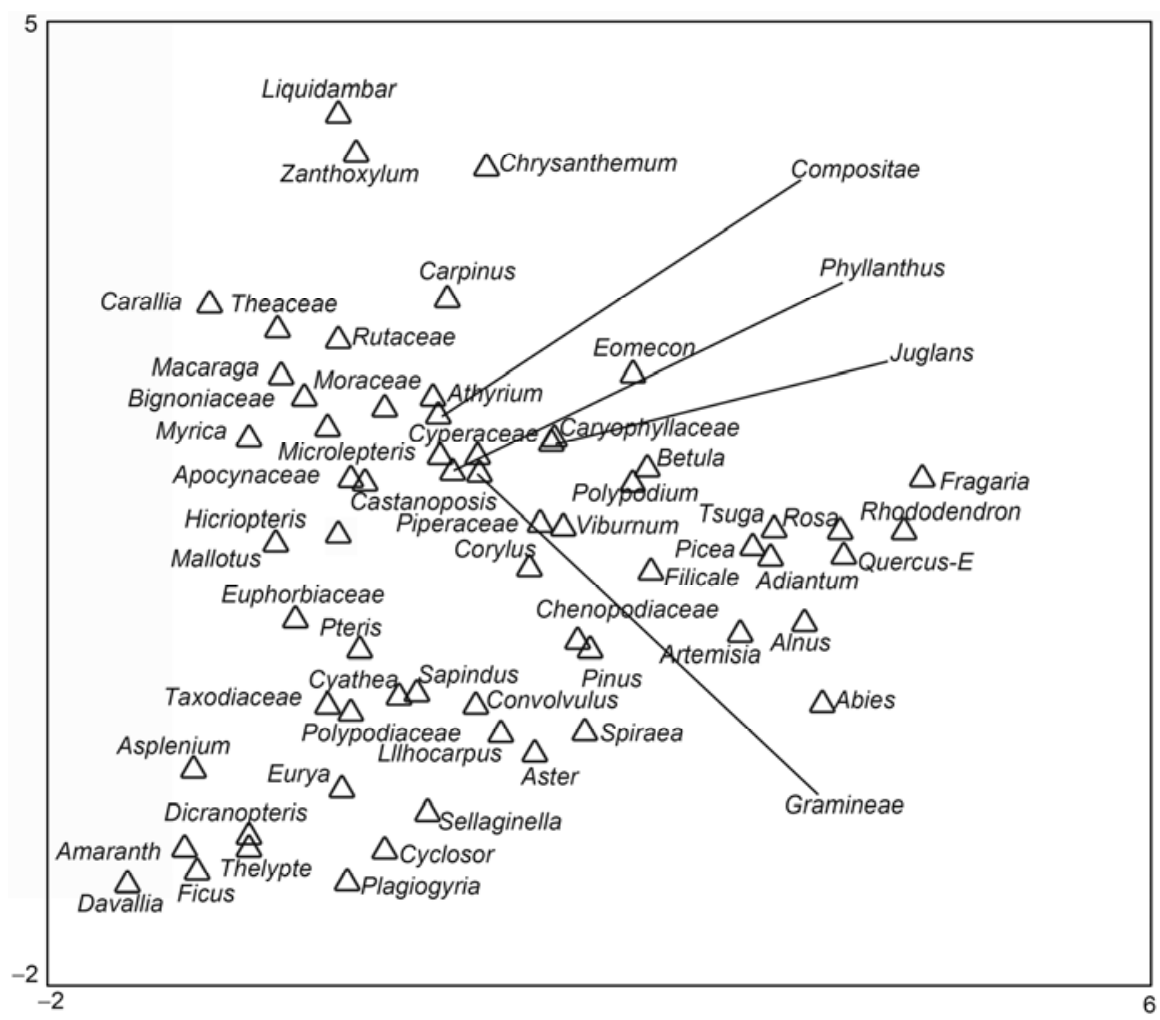

Figure 5 The species distribution diagram. 
types in the high latitude or high elevation. $P$. armandii and mountain forest, temperate deciduous conifer mixed forest and $P$. yunnanensis remain difficult to distinguish.

\section{Explanation and discussion}

Variations in the content of pollen of tropical and subtropical evergreen broadleaf tree are relatively consistent with the vegetation distribution. Ficus, Moraceae, Eurya, Lithocarpus, and Castanopsis are common plants in tropical and subtropical sites. The relative content of pollen from these species is the highest in the tropical and subtropical soil samples. There is a good corresponding relationship between vegetation and pollen spectrum of tropical seasonal rainforest and mountain rainforest. The high number of species and high content of tropical and subtropical broadleaved trees and ferns spore pollen reflect the diversity of the tropical vegetation, and also provide the key to distinguishing them from other vegetation types. The subtropical elements found in subtropical evergreen broad-leaved forest, $P$. kesiya forest and subtropical evergreen broad-leaved forest (such as the high content of Castanopsis, Cyclobalanopsis and Moraceae pollen) prove useful in distinguishing them from other types of vegetation. The dominant relative frequency of Quercus evergreen compared to Pinus pollen in the Quercus shrub pollen spectra is the key to distinguishing these communities from other vegetation types.

The results of determination of the pollen frequency spectrum and DCA analysis reveals the difficulty in making precise distinctions between different types of cool temperate vegetation communities based on pollen alone, in subtropical zones through to Yulong Snow Mountain. This uncertainty exists mainly when Pinus pollen is dominant and over-represented in the samples. Previous work in Yunnan and its adjacent areas showed that the content of Pinus pollen in the northern area of the south subtropical area is very high, while that of constructive species is low, however, we can distinguish different vegetation types based on high content of constructive species [21,22,36-40]. In this paper, all samples were taken from cold temperate deciduous conifer mixed forest. The content of Picea, Abies and Tsuga pollen is lower than $5 \%$, which is less than that of pure forest, therefore, these communities can not be adequately differentiated.

\subsection{Pinus}

The over-representation effect in Pinus pollen is a feature of all of the 61 surface soil samples. The content of Pinus pollen from subtropical broad-leaved forest to cold-temperate coniferous and broad-leaved mixed forest is over $50 \%$, with the highest reaching $93.7 \%$. The over-representation effect of Pinus pollen is the main factor which precludes differentiation between broadleaf and coniferous forest. Based on the observations, we conclude that there are two reasons for the apparent lower content of Pinus pollen in secondary Quercus shrub: one is the representation of Quercus. Previous research found that the representation of Quercus pollen in the samples and sites is considerable, at least equivalent to the relative content of the vegetation $[41,42]$. The other factor is terrain, which can be an obstacle for Pinus pollen transport to the locations where mountain oak is a more common component of the forest stand. Collections of recent surface pollen in the Yulong Snow Mountain region show that the content of Pinus pollen located above $2000 \mathrm{~m}$ is over $60 \%$, and the amount of Pinus pollen of surface pollen in modern lakes in Sichuan is more than 50\% [22,39]. Topography may be the main factor leading to lower content of Pinus pollen in Quercus shrub.

Broad-leaved forest can be distinguished from coniferous forest by Pinus stomata. A sample of the evergreen broadleaved forest contains $P$. yunnanensis stomata mainly because they grew at that sampling point. Since Pinus stomata can be identified to species, different Pinus are readily distinguished. Sikaya, Matsu and P. yunnanensis stomata are only found with $P$. kesiya, $P$. yunnanensis and $P$. armandii, while $P$. densata are distributed in high altitude and latitude. Pinus stomata are not found at sites where Pinus is absent. However, stomata do not appear in some of the samples which have Pinus pollen, such as the samples 15, 23 and 25, which containe $P$. kesiya, but no stomata. Sample 37 has signifcant growth of $P$. yunnanensis and $P$. armandii, but not their stomata, however a large number of Pinus stomata which cannot be identified to species are found. Samples 40 and 42 contain Pinus stomata, but Pinus densata Mast. stomata cannot be found, although it is clear that Pinus densata Mast. trees existed at the sites. These cases illustrate that identification of stomata species is the key to distinguishing different kinds of Pinus. Sample burial conditions and experimental processes may affect stomatal morphology thereby limiting the precise identification of the stomata.

The relative abundance of Pinus stomata is the highest of all conifer species in the study area. The samples with the highest proportion of Pinus stomata are found in sample points where the pine trees or pure forest are dominant.

\subsection{Picea}

As a result of the over-representation effect of Pinus pollen, the content of Yulong Snow Mountain's Picea pollen reached a maximum of $39.1 \%$, although most samples do not exceed $20 \%$ [19]. In this study, the proportion of Picea forest is low and its pollen content is even lower, not exceeding $1 \%$. Picea is found in or adjacent to the areas of samples 40,53, and 55-58, but the content of their stomata is $0.3 \%-5.5 \%$, much higher than the corresponding pollen percentage. However, Picea is not found adjacent to the locations of samples 45, 46, 54 and 61, and yet Picea stomata appeares in the samples. These samples are located at 
an altitude of over $3300 \mathrm{~m}$ where the Picea-Abies forest is distributed previously. After human-caused deforestation, secondary $P$. densata and $Q$. spinosa grew instead. Picea stomata may come from the surface soil. Another possible explanation for Picea and Abies stomata being found in Sample 61 assumes that leaves from the nearby Picea-Abies forest might have been blown to this sampling location by wind, since Quercus forest is located on the ridges and cold Picea forest is located on the northern slope.

\subsection{Abies}

Samples containing Abies are located in two places: one is the strip with an elevation of about 3100-3300 m in Cangshan, which supports Abies, Tsuga, Quercus evergreen and Rhododendron mixed forest. The proportion of coniferous forest is less than $10 \%$. Primitive forest at the locations of samples 47 and 48 had been cut down, and thereafter generated mainly dominant Spiraea and Rubus shrubs. Another location is a narrow zone at elevation $3300-3600 \mathrm{~m}$ in Yulong Snow Mountain, where originally Picea and Picea forest dominated, but which is replaced by secondary forest cover after cutting, resulting in re-growth dominated by young $Q$. spinosa, Picea and Abies. Abies pollen had low representation, but its proportion in the Abies forest is still relatively high $[43,44]$. Abies are the dominant species in cold-temperate coniferous and broad-leaved mixed forest in southwest Sichuan, although its pollen content is not more than $10 \%$, making it a "low" represented species [37,39]. The proportion of Abies is low in the sample points and its pollen content is even lower, with highest peak of $2.2 \%$, but most of the samples have less than $1 \%$, and mainly distributed around where the Abies grow. However, no Abies occurred at some of the sampling points, although Abies pollen could be found. Abies pollen could not be found in samples 49, 54-56. Abies stomatal content varied from $0.1 \%$ to $22 \%$ and no stomata have been found in samples 49,51 , 54-57. The Abies trees are scarce in the vicinity of the samples points and no or few pollen have been found, suggesting that the existence of Abies trees cannot be indicated by pollen and stomata in the cases with a very low proportion of Abies trees. Samples 59-61 belonged to secondary $Q$. spinosa shrubs. There is no Abies growing here, but stomata are present, for example, Sample 61 whose stomata content reached $22 \%$. Possible causes are similar to those of Picea stomata.

\subsection{Tsuga}

Tsuga pollen distributed over a very wide range, from subtropical Pinus kesiya forest to $Q$. spinosa shrub, however, the content is generally below $1 \%$. In the Quercus evergreen-Tsuga-Abies forest samples, the highest content of Tsuga is $1.7 \%$, with the others making up less than $1 \%$. Among all of the surface soil samples, the content of Tsuga in Sample 39 is the highest, reaching 5\%, and at the same time, stomatal content is the highest, reaching $33.8 \%$. However, Tsuga did not occur near the sampling point. The Tsuga pollen and stomata may have come from Tsuga forest, which is located in the upper mountain (the highest peak of the mountain has an elevation of $3942 \mathrm{~m}$ ). The sampling point with significant Tsuga growth contains a certain amount of stomata, indicating that the observed presence of Tsuga stomatal can indicate the growth of Tsuga.

\subsection{Keteleeria and Larix}

Keteleeria grow mainly at the location of Sample 37. No Keteleeria pollen has been found but Keteleeria stomata appear in the sample, suggesting that the stomata may be a better indicator than pollen to identify the parent plants. Sample 53 is a Rhododendron-Abies forest. Larch is been found within 100 meters around the sampling point, but large Sequoia also appear. Larch pollen is absent, but Larch stomata $(1.3 \%)$ are observed in the sample. Stomata may be transported by water or wind, although Larch trees occupy a small proportion of the forest. Larch drops the leaves annually, and therefore the stomatal content of the topsoil tends to be relatively high.

The analysis above shows that conifer stomata is a good indicator of the parent plants in most cases, even if the parent plants are rare in the forest. Pinus stomata can be identified to species, and used to reliably distinguish different types of pine forest. Hansen found that conifer stomata could only indicate the existence of the parent plants [14], however, in this paper, higher values of the stomata counts always appeared in the samples with a high value of abundance of the parent plants, demonstrating that high levels of stomata may indicate the abundance of the plants. This analysis of Yunnan surface pollen and stomata shows that evaluating both stomata and pollen can effectively assist in reconstructing the vegetation.

\section{Conclusions}

The results of sampling modern surface pollen in Yunnan show that tropical rainforest and mountain rainforest, subtropical vegetation and $Q$. spinosa shrub can be distinguished effectively from other vegetation types by pollen. However, the south Asian tropical broad-leaved forest, coniferous and broad-leaved mixed forest and Pinus kesiya forest cannot be distinguished from the others. Due to the over-representation effect of the Pinus pollen, subtropical broad-leaved forest, $P$. yunnanensis forest and its mixed forests, $P$. armandii, $P$. densata forests and its mixed forests, temperate coniferous and broad-leaf forests and Abies forests cannot be distinguished effectively from the others by pollen.

Conifer stomata can effectively add to the value of pollen 
analysis, to distinguish different types of coniferous forests and its mixed forests. Stomata data indicate the presence of the parent plants, even when Tsuga, Abies and Picea trees occupied such a small proportion of the forests that pollen of surface samples are not sufficient to indicate the existence of these trees.

Vertical vegetation zones existed in the mountainous because the stomata in the high altitude area may be transported to the low altitude areas by wind or water transportation.

The topsoil study in this paper shows that stomata could effectively assist with pollen analysis to reconstruct the vegetation.

This work was supported by the National Natural Science Foundation of China (40872116, 41172151, 40871073). The authors thank to Mr. Yue Zhongshu of Kunming Institute of Botany, Chinese Academy of Sciences who contributed to identification of plants, Mr. Liu Zhiming of Institute of Hydrogeology \& Engineering Geology, CAGS who assisted with field work, and Miss Shao Liwei of Nanjing Hydraulic Research Institute who checked the paper patiently.

1 Luo Y L, Sun X J. Vegetation evolution and millennial-scale climatic fluctuations since Last Glacial Maximum in pollen record from northern South China Sea. Chin Sci Bull, 2005, 50: 793-799

2 Xiao X Y, Shen J, Wang S M, et al. The plant diversity and its relationship with paleoenvironment since 2.78 Ma revealed by pollen records in the Heqing deep drilling core. Chin Sci Bull, 2008, 53: 3686-3698

3 Birks H H. The importance of plant macrofossils in late-glacial climatic reconstructions: An example from western Norway. Quat Sci Rev, 1993, 12: 719

4 Clayden S L, Cwynar L C, MacDonald G M, et al. Holocene pollen and stomates from a forest-tundra site on the Taimyr Peninsula, Siberia. Arct Antarct Alp Res, 1997, 29: 327-333

5 Trautmann W. Zur unterscheidung fossiler spaltoffnungen der mitteleuropaischen coniferen. Flora, 1953, 140: 523-533

6 Parshall T. Documenting forest stand invasion: Fossil stomata and pollen in forest hollows. Can J Bot, 1999, 77: 1529-1538

7 Hansen B C S, MacDonald G M, Moser K A. Identifying the tundra forest border in the stomate record: An analysis of lake surface samples from the Yellowknife area, Northwest Territories, Canada. Can J Bot, 1996, 74: 796-800

8 MacDonald G M. Conifer Stomata. In: Smol J P, Birks H J B, Last W M, eds. Tracking Environmental Change Using Lake Sediments. Dordrecht: Kluwer Academic Publishers, 2001. 33-47

9 David F. Holocene tree limit history in the northern French Alps stomata and pollen evidence. Rev Palaeobot Palyno, 1997, 97: 227237

10 Pisaric M F J. Holocene treeline dynamics in the mountains of northeastern British Columbia, Canada, inferred from fossil pollen and stomata. Holocene, 2003, 13: 161-173

11 Froyd C A. Fossil stomata, reveal early pine presence in Scotland: Implications for postglacial colonization analyses. Ecology, 2005, 86: 579-586

12 Pisaric M F J, Szeicz Julian M, Karst Tammy, et al. Comparison of pollen and conifer stomates as indicators of alpine treeline in northwestern Canadian lake sediments. Can J Bot, 2000, 78: 1180-1186

13 Yu Z. Late Quaternary paleoecology of Thuja and Juniperus $(\mathrm{Cu}-$ pressaceae) at Crawford Lake, Ontario, Canada: Pollen, stomata and macrofossils. Rev Palaeobot Palyno, 1997, 96: 241-254

14 Hansen B C S. Conifer stomate analysis as a paleoecological toolan example from the Hudson-bay lowlands. Can J Bot, 1995, 73: 244 252

15 Kennedy L M, Horn S P, Orvis K H. Modern pollen spectra from the highlands of the Cordillera Central, Dominican Republic. Rev Palaeobot Palyno, 2005, 137: 51-68

16 Li C H, Tang L Y, Wan Hewen, et al. Vegetation and human activity in Yuyao (Zhejiang Province) inferred from the Sporo-Pollen record since the Late Pleistocene (in Chinese). Acta Micropalaeontol Sin, 2009, 26: 48-56

17 Zhang K, Zhao Y, Guo X L. Conifer stomata analysis in paleoecological studies on the Loess Plateau: An example from Tianchi Lake, Liupan Mountains. J Arid Environ, 75: 1209-1213

18 Guobang T, Zhiming L, Wang S, et al. Reconstruction of climatic sequence of the past $1 \mathrm{ma}$ in the Heqing Basin, Yunnan Province. Quat Sci, 2002, 22: 332-339

19 Xiao X Y, Shen J, Xiao H F, et al. Paleoegetation and paleoclimate of the Heqing basin during 2.780-1.802 mab.p.in Yunnan province, China. Quat Sci, 2007, 27: 417-426

20 Xiao X Y, Shen J, Xiao H F, et al. Paleovegetation and paleoclimate of the Heqing Basin during 2.780-1.802 mab.p. in Yunnan Province, China (in Chinese). Quat Sci, 2007, 27: 417-426

21 Li C H, Tong G B, Shen J, et al. A study of surface pollen on an elevational gradient in Lijiang and Dali areas, Yunnan Province, China (in Chinese). Acta Palaeontol Sin, 2008. 47: 168-175

22 Xiao, X Y, Shen J, Wang S M. Spatial variation of modern pollen from surface lake sediments in Yunnan and southwestern Sichuan Province, China. Rev Palaeobot Palyno, 2011, 165: 224-234

23 Wright H E Jr. The use of surface samples in Quaternary pollen analysis. Rev Palaeobot Palyno, 1967, 2: 321-330

24 Sweeney C A. A key for the identification of stomata of the native conifers of Scandinavia. Rev Palaeobot Palyno, 2004, 128: 281-290

25 Clayden S L, Cwynar L C, MacDonald G M. Stomate and pollen content of lake surface sediments from across the tree line on the Taimyr peninsula, Siberia. Can J Bot, 1996, 74: 1009-1015

26 Gervais B R, MacDonald G M. Modern pollen and stomate deposition in lake surface sediments from across the treeline on the Kola Peninsula, Russia. Rev Palaeobot Palyno, 2001, 114: 223-237

27 Leitner R, Gajewski K. Modern and Holocene stomate records of tree-line variations in northwestern Quebec. Can J Bot, 2004, 82: 726-734

28 Pisaric M F J, MacDonald Glen M, Cwynar Les C, et al. Modern pollen and conifer stomates from north-central Siberian lake sediments: Their use in interpreting late quaternary fossil pollen assemblages. Arct Antarct Alp Res, 2001, 33: 19-27

29 Wu Z Y, Zhu Y C, Jiang H Q, et al. Vegetation of Yunnan. Beijing: Science Press, 1987

30 Faegri K, Kaland P E, Krzywinski K. Textbook of Pollen analysis. West Sussex: John Wiley \& Sons Ltd, 1989

31 Hansen B C S. Conifer stomate analysis as a paleoecological tool: An example from the Hudson Bay Lowlands. Can J Bot, 1995, 73: 244-252

32 Wan H W, Shen J, Tang L Y, et al. Morphology of stomata of pinaceae and Cupressaceae from northwestern China (in Chinese). Acta Micropalaeontol Sin, 2007, 24: 309-319

33 Grimm, E C. TILIA 2.0. Illinois State Museum. Heidelberg: Springer, 1990

34 Grimm, E C. TILIA Graph v. 2.0.2. Illinois State Museum, Research and Collection Center. Heidelberg: Springfield, 2004

35 Ter Braak C J F, Canoco S P. Reference manual and user's guide to Canoco for Windows: Software for Canonical Community Ordination (version 4). Microcomputer Power, Ithaca, NY, USA, 1998

$36 \mathrm{Wu}$ Y S, Sun X J. A preliminary study on the relationship between the pollen percentages in forest surface samples and surrounding vegetation on west mountain of Kunming, Yunnan. J Integr Plant Biol, 1987, 29: 204-211

37 Li X, Liu J L. Holocene vegetational and environmental changes at Mt. Luoji, Sichuan (in Chinese). Acta Geograph Sin, 1988, 43: 4450

38 Chen Y S, Wu Y S, and Xiao J Y. The study on topsoil pollen in Kunming (in Chinese). J Integr Plant Biol, 1991, 33: 855-862

39 Jarvis D I, Clay-Poole S T. A comparison of modern pollen rain and vegetation in southwestern Sichuan Province, China. Rev Palaeobot 
Palyno, 1992, 75: 239-258

40 Tong G B, Yang X D, Liu Z M, et al. Surface soil pollen distributions in the Yulong Mountain (in Chinese). Mar Geo Quat Geo, 2003, 23: 103-107

41 Li W Y, Yao Z J. Center and North Subtropical Vegetation and Environmental Research During Quaternary in China. Beijing: Ocean Press, 1993. 14-26

42 Liu H P, Xie L D. A study on the representation of some main pol- lens in Shennongjia region (in Chinese). J Cent Chin Norm Univ (Nat Sci), 1998, 32: 495-497

43 Li W Y. Relationships between pollen and plant of the Abies Fargesii forest and its succession in the Shennongjia Mountains (in Chinese). Acta Geograph Sin, 1991, 46: 186-193

$44 \mathrm{Li} \mathrm{Y} \mathrm{C,} \mathrm{Xu} \mathrm{Q} \mathrm{H,} \mathrm{Xiao} \mathrm{J} \mathrm{L,} \mathrm{et} \mathrm{al.} \mathrm{Indication} \mathrm{of} \mathrm{some} \mathrm{major} \mathrm{pollen} \mathrm{taxa}$ in surface samples to their parent plants of forest in northern China (in Chinese). Quat Sci, 2005, 25: 598-608

Open Access This article is distributed under the terms of the Creative Commons Attribution License which permits any use, distribution, and reproduction in any medium, provided the original author(s) and source are credited. 